\title{
Morphological and Elemental analysis of the effluent of Lead-acid battery manufacturing
}

\author{
Narasimhulu Korrapati ${ }^{*}$, Paramjeet Saroj, Nisha Gaur \\ Department of Biotechnology, National Institute of Technology, Warangal, India.
}

\begin{tabular}{|c|c|}
\hline ARTICLE INFO & ABSTRACT \\
\hline $\begin{array}{l}\text { Article history: } \\
\text { Received on: } 02 / 02 / 2017 \\
\text { Accepted on: } 18 / 04 / 2017 \\
\text { Available online: } 19 / 06 / 2017\end{array}$ & $\begin{array}{l}\text { Excessive release of Lead }(\mathrm{Pb}) \text { contaminated effluent into the water bodies become the lead poisonous. This } \\
\text { waste water is the main source for the transfer of Lead }(\mathrm{Pb}) \text { into the living organisms. Lead }(\mathrm{Pb}) \text { is a } \\
\text { poisonous heavy metal that accumulates in the tissues of organisms when it is taken excessively through } \\
\text { drinking water. This bioaccumulation disturbs functional activity of the tissues in living organisms. In this }\end{array}$ \\
\hline $\begin{array}{l}\text { Key words: } \\
\text { Energy Dispersive X-ray (EDX), } \\
\text { Inductively Coupled Plasma- } \\
\text { Atomic Emission Spectrometry } \\
\text { (ICP-AES), Lead (Pb), } \\
\text { Morphology, Scanning Electron } \\
\text { Microscope (SEM). }\end{array}$ & $\begin{array}{l}\text { research the morphology of the lead }(\mathrm{Pb}) \text { compound precipitate powder was analyzed using Scanning electron } \\
\text { microscope }(\mathrm{SEM}) \text {. This precipitate was also analyzed for the elemental composition using Energy dispersive } \\
\mathrm{X} \text {-ray (EDX), which is coupled with SEM. From the EDX results, Weight and Atomic percentages of Lead } \\
(\mathrm{Pb}) \text { in the precipitate were } 62.81 \text { and } 13.05 \text { respectively in spectrum } 1 \text { and } 69.32 \text { and } 17.51 \text { respectively in } \\
\text { the spectrum } 2 \text {. And also the concentration of lead }(\mathrm{Pb}) \text { was determined as } 1.21 \mathrm{mg} / \mathrm{L} \text { using Inductively } \\
\text { Coupled Plasma-Atomic Emission Spectrometry (ICP-AES). Temperature, pH, Chemical oxygen demand } \\
(\mathrm{COD}) \text {, Biochemical oxygen demand (BOD) and turbidity of the effluent were also measured as } 14^{0} \mathrm{C}, 2.34 \text {, } \\
448 \mathrm{mg} / \mathrm{L}, 173 \mathrm{mg} / \mathrm{L} \text { and } 163.4 \text { NTU respectively. }\end{array}$ \\
\hline
\end{tabular}

\section{INTRODUCTION}

Heavy metals such as arsenic, cadmium, chromium, copper, lead, mercury and zinc are not degradable by living organisms and hence they are accumulated in the cells of living organisms especially humans through various mechanisms including complexation, adsorption, precipitation and active transport. This causes damage to the tissues $[1,2,15,16]$. There are two ways for heavy metals to reach humans through water bodies and food derived from water bodies [6]. There are permissible limits to these heavy metals release into the water bodies given by the different organizations like EPA, WHO and Indian standards, which indicate exceeding of that permissible limits causes severe hazardous to the environment. Therefore they should not be exceeded more than those permissible limits. But heavy metals are released into the water bodies from accidental discharges of industries such as alloy manufacturing, cosmetics, electroplating, chemical fertilizers and pesticides, lead batteries, glass operations, metal plating, mining, paint and

\footnotetext{
* Corresponding Author

Email:simha_bt @ nitw.ac.in
}

pigments [3, $4 \& 7]$. Since the permissible limits of heavy metals are being exceeded in the drinking water and wastewater, pollution from heavy metals has become a serious problem all over the world [5]. There are five routes to exhibit the toxicity of heavy metals such as binding and blocking the essential functional groups biomolecules such as carbohydrates, lipids, proteins and specially enzymes; removing essential metal ions from their native binding sites; disturbing the conformational structure of biomolecules; degrading essential metabolites; and changing the ion transport across the cells [12]. In this manner pressures from these toxic metal polluted environment disturbs the metabolic activities of living organisms [14]. So the survival ability of the organism in the presence of metal toxicity depends on its intrinsic properties [15 \& 16]. Lead $(\mathrm{Pb})$ is one of the heavy metals used in various manufacturing units such as mining, smelting and battery manufacturing $[8,9,17 \& 18]$. Lead is discharged in to the nature by anthropogenic activities and entered into the food chain $[10 \&$ 11]. $\mathrm{Pb}$ is not useful element to the plant and animals. The toxic effects of $\mathrm{Pb}$ depend on its concentration and the age of person exposed. Low concentration of $\mathrm{Pb}$ affects the mental and physical growth of children. Exposure of high concentrations of $\mathrm{Pb}$ leads to the anemia, brain damage, hyper tension, muscle weakness and kidney problems finally reach to death in children $[17,18]$. 
Lead pollution affects metabolic activity, respiration, membrane transport and ribosome and protein synthesis and activities, which results in the cell death [13]. According to the Indian Standard (IS 10500 1992), EPA and WHO the maximum allowable limits of $\mathrm{Pb}$ (II) ion concentration in drinking water $0.05,0.015$ and $0.01 \mathrm{mg} / \mathrm{L}$ respectively [20-23]. The significance of morphological and elemental compositional characterization of chemical compounds has recently been receiving great importance, because these studies provide useful information about chemical properties, sources and history of the chemical compounds [29, 30, 31]. So the elemental analysis of a particle gives information about the source, formation and effect on environment health [30, 34]. Therefore Scanning electron microscopy with Energy-dispersed Xray analysis (SEM/EDX) was commonly used for morphological and elemental compositional analysis of precipitated chemical compounds [32,33]. Based on the above analysis, in this paper morphology and chemical compositional analysis was performed using SEM-EDX for identification of lead $(\mathrm{Pb})$ and investigated concentration of $\mathrm{Pb}$ with the physicochemical parameters in the effluent from Lead acid battery industry.

\section{MATERIALS AND METHODS}

\subsection{Chemicals}

All the chemicals used in the protocols were purchased from Sigma, Himedia and Merck.

\subsection{Sample collection}

Effluent sample was collected and preserved according to the APHA from Nile Limited battery manufacturing, Nalgonda, Telangana, India [19].

\subsection{Lead (Pb) detection}

Effluent sample $\mathrm{pH}$ was increased by adding $\mathrm{NaOH}$. Then samples were incubated 48 hours. Formed precipitation was removed and then completely dried at $50^{\circ} \mathrm{C}$ in the hot air oven (Thermo scientific). After that that dried precipitate was converted into powder form and sent to computer controlled SEM (VEGA3 TESCAN LMU) and EDX (INCAx-act, 51-ADD0007) for morphological and elemental analysis [25]. Powder was poured and spread over on the plastic stubs for gold coating. Gold coating was done on the powder sample using vacuum coating unit called Gold Sputter Coater (SPI-MODULE). This was made the sample electrically conductive. Then the sample was placed in the SEMEDX chamber. Then the operating condition was set to $15 \mathrm{kV}$ voltages. Images were taken at different ranges. Then the EDX analysis was also performed at specific points in terms of both qualitatively and quantitatively. The weight and atomic percentage of the elements present in the spectrum $1 \& 2$ were measured.

\subsection{Lead Determination}

Lead concentration in the effluent was determined by inductively coupled plasma method using ICP-AES (Model:
ARCOS from M/s. Spectro, Germany). General Specification of ICP-AES as given in the source website IIT Bombay [24].

Table 1: General Specification of ICP-AES

\begin{tabular}{cl}
\hline R.F. Generator & \multicolumn{1}{c}{ Maximum of 1.6 KW, 27.12 MHz } \\
\hline Plasma & $\begin{array}{l}\text { Radial plasma, having capability to analyze aqueous } \\
\text { solutions with high dissolved solid content even up to } \\
30 \mathrm{wt} \% \text {. Aqueous solutions can be acidic, basic or } \\
\text { neutral }\end{array}$ \\
\hline \multirow{3}{*}{ Spectrometer } & $\begin{array}{l}\text { Wavelength Range: 130 nm to 770 nm, Resolution: } \\
\text { approx. 9 Pico meter, having capability to scan full } \\
\text { spectrum to have qualitative information about the } \\
\text { content of the sample }\end{array}$ \\
\hline Torch & Charge Coupled Devices (CCD) \\
\hline \multirow{2}{*}{ Nebulizers } & $\begin{array}{l}\text { Vertical Torch assembly having fully demountable } \\
\text { quartz torch with individual tubes as well as a Ceramic } \\
\text { Fully demountable torch for HF based solutions }\end{array}$ \\
\hline \multirow{2}{*}{ Spray chambers } & $\begin{array}{l}\text { Concentric, cross flow, organic nebulizer } \\
\text { (hydrocarbons, solvents) as well as cross flow } \\
\text { nebulizer for HF containing solutions }\end{array}$ \\
\hline & $\begin{array}{l}\text { HF Resistant Cyclonic Chamber and hydrocarbon } \\
\text { solution spray chamber. Spray chambers } \\
\text { suitable for cross flow Nebulizers are available }\end{array}$ \\
\hline
\end{tabular}
For the measurement of $\mathrm{Pb}$ concentration, the EPA 200.7 certificated sample preparation method was used (Method 200.7, 1994; APHA, AWWA, WPCF, 1992).

\subsection{Physical and Chemical Characterization}

The $\mathrm{pH}$ and temperature were measured using $\mathrm{pH}$ meter with their manual (Oakton pH 700) [28]. COD and BOD were also determined [19]. Turbidity was measured using nephlometer (Elico CL 52D).

\section{RESULTS and DISCUSSION}

\subsection{Lead (Pb) Detection}

Many reactions are usually $\mathrm{pH}$ dependant. So $\mathrm{pH}$ plays an important role in those reactions. Due to the $\mathrm{pH}$ adjustment compounds present in the solution are being precipitated. Based on this, the effect of $\mathrm{pH}$ on the effluent solution was investigated in this research. Precipitation was formed in the effluent sample, when the $\mathrm{pH}$ was increased to $\mathrm{pH} 14.0$ using $\mathrm{NaOH}$ from initial $\mathrm{pH}$, since initial $\mathrm{pH}$ of the effluent was 2.34. After incubation for 48 hours precipitation formation was started at $\mathrm{pH} 3.23$. More amount of precipitate was formed at $\mathrm{pH} 7.57$ [25 \& 26]. This precipitation was completely dried after removal and converted into powder. Then precipitate powder was captured in different resolutions using SEM. The precipitate powder looks as small rod like particles as shown in all figures. Figures 1, 2, 3 and 4 show images of precipitate powder particles in 2, 5, 10 and $20 \mu \mathrm{m}$ resolutions respectively. Single rod image of precipitate particle was shown at $2 \mu \mathrm{m}$ range in figure 1 . The elemental composition analysis of precipitate particle was done using EDX at spectrum 1 and 2 as shown in figures 5 and 6 . Analysis on the precipitate particles revealed that both spectrums contain $\mathrm{O}$ (Oxygen), S (Sulphur) and $\mathrm{Pb}$ (Lead). The elemental composition percentages are tabulated in Table $2 \& 3$ for spectrum 1 and 2 respectively. From the Table 2, it shows that the precipitate particles at Spectrum 1 contain $\mathrm{O}, \mathrm{S}$ and $\mathrm{Pb}$ with the weight percentages of $27.47,9.71$ and 62.81 respectively. 


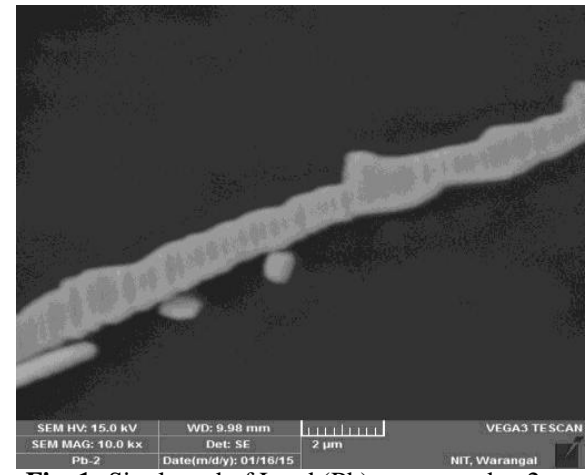

Fig. 1: Single rod of Lead $(\mathrm{Pb})$ compound at $2 \mu \mathrm{m}$.

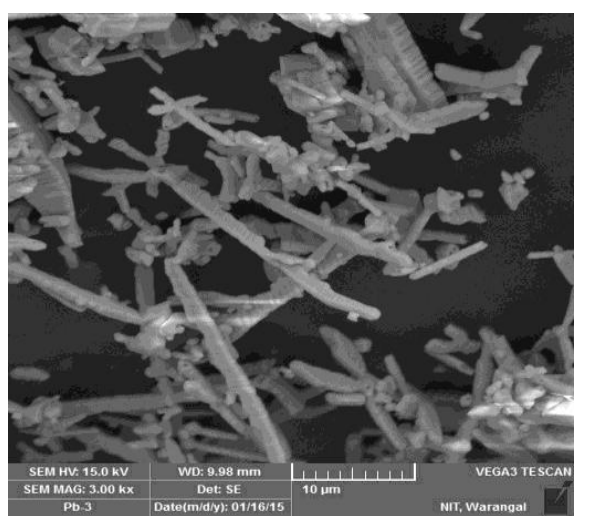

Fig. 3: Rods of Lead $(\mathrm{Pb})$ compound at $\mathbf{1 0 \mu m}$.

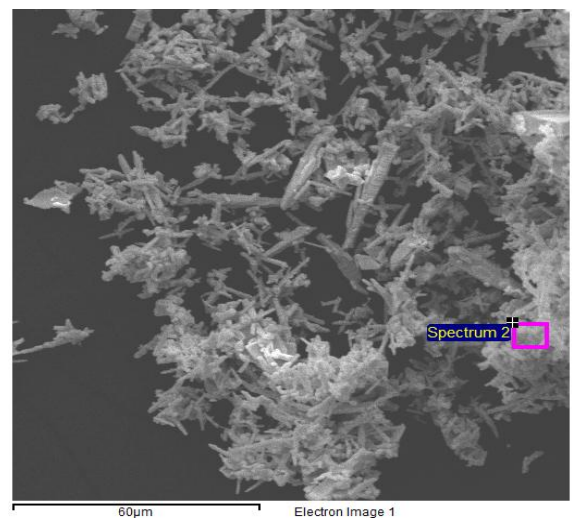

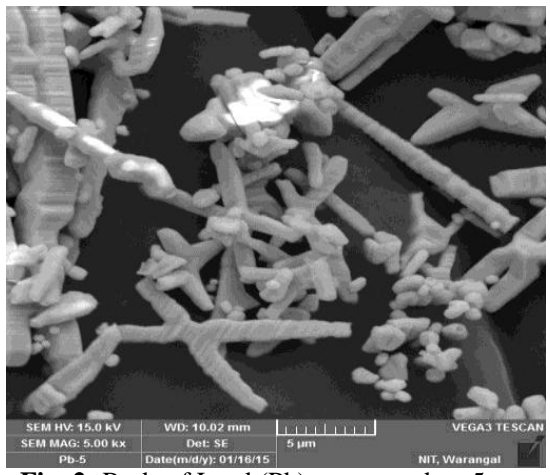

Fig. 2: Rods of Lead $(\mathrm{Pb})$ compound at $5 \mu \mathrm{m}$.

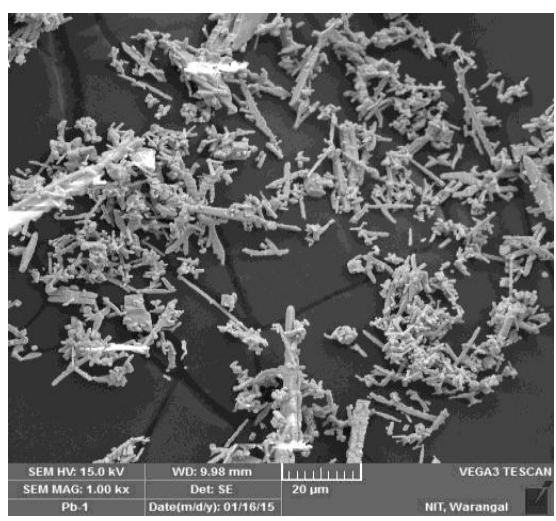

Fig. 3: Rods of Lead $(\mathrm{Pb})$ compound at $20 \mu \mathrm{m}$.

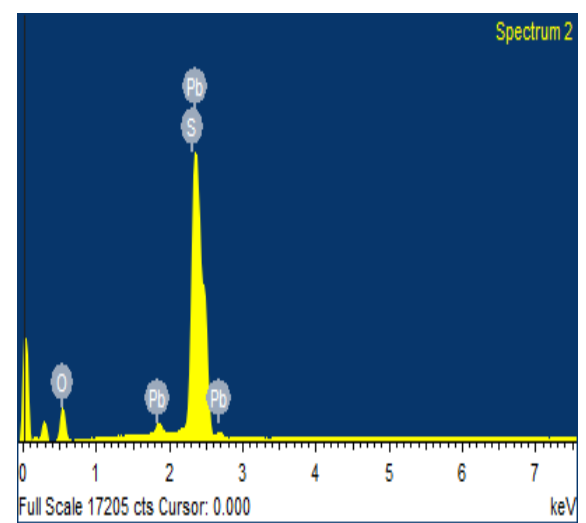

Fig. 5: EDX analysis for spectrum 1
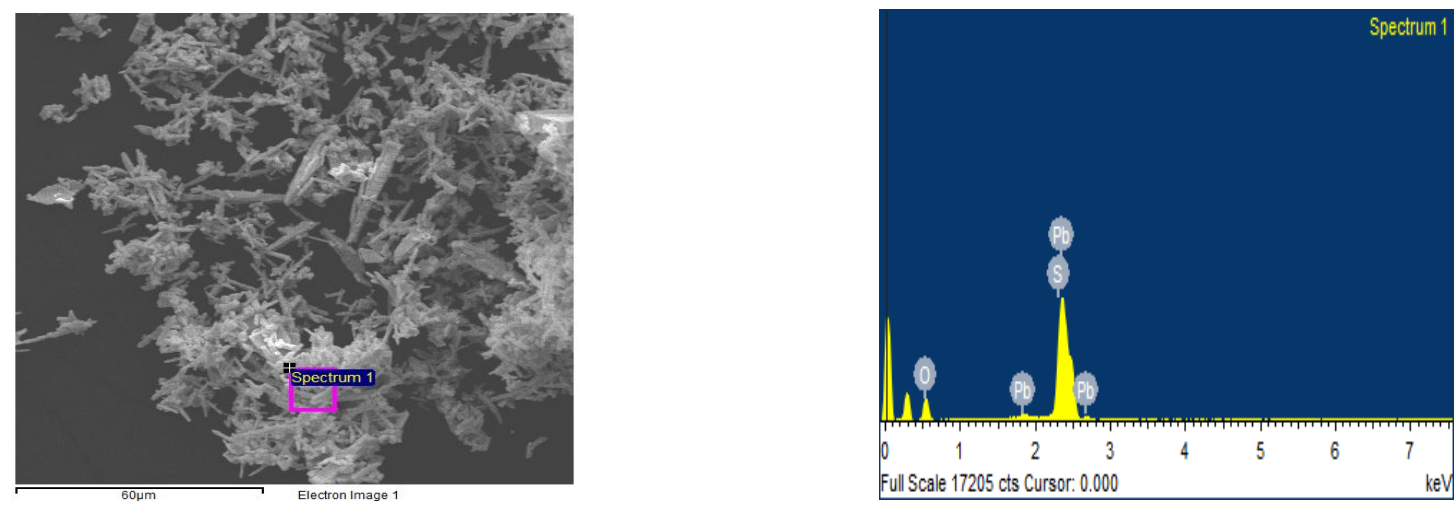

Fig. 6: EDX analysis for spectrum 2 
percentages of $19.78,10.90$ and 69.32 respectively. However, the analysis of both spectrums revealed that the element with the highest weight percentage is Lead $(\mathrm{Pb})$. A higher percentage of $\mathrm{Pb}$ reflected a higher amount of $\mathrm{Pb}$ element throughout the spectrum.

Table 2: Elemental analysis of Spectrum 1

\begin{tabular}{ccc}
\hline Element & Weight\% & Atomic\% \\
\hline $\mathrm{O}$ & 27.47 & 73.91 \\
$\mathrm{~S}$ & 9.71 & 13.04 \\
$\mathrm{~Pb}$ & 62.81 & 13.05 \\
\hline
\end{tabular}

Table 3: Elemental analysis of Spectrum 2

\begin{tabular}{ccc}
\hline Element & Weight\% & Atomic\% \\
\hline $\mathrm{O}$ & 19.78 & 64.69 \\
$\mathrm{~S}$ & 10.90 & 17.80 \\
$\mathrm{~Pb}$ & 69.32 & 17.51 \\
\hline
\end{tabular}

\subsection{Lead Determination}

Lead $(\mathrm{Pb})$ concentration in the effluent was analyzed by ICP-AES. The concentration of $\mathrm{Pb}$ was determined as $1.21 \mathrm{mg} / \mathrm{L}$. This value shows that the concentration is more than the permissible range according to the EPA, WHO and Indian standards. So the effluent from this industry must be treated to reduce the concentration of $\mathrm{Pb}$ before releasing into the environment.

\subsection{Physicochemical characteristics}

Temperature, $\mathrm{pH}, \mathrm{COD}, \mathrm{BOD}$ and turbidity values are 14 ${ }^{0} \mathrm{C}, 2.34,448 \mathrm{mg} / \mathrm{L}, 173 \mathrm{mg} / \mathrm{L}$ and $163.4 \mathrm{NTU}$ (Nephelometric turbidity units) respectively as shown in the Table 4 . Temperature is below than the room temperature. This $\mathrm{pH}$ is less than the Indian standards.

This indicates that the effluent was in acidic nature. COD, BOD and turbidity values are also greater than the Indian standards, which are in dangerous level to the aqua living organisms. If this effluent releases into the water bodies with the above parameter values, then the water bodies will be polluted. Consequently, this will affect the health of the organisms living in that environment and can reach to human beings through food cycle.

Table 4: Physicochemical Characteristics.

\begin{tabular}{ccc}
\hline Parameter & Value & $\begin{array}{c}\text { Indian Standards for } \\
\text { effluent discharges }\end{array}$ \\
\hline Temperature & $14^{0} \mathrm{C}$ & \\
pH & 2.34 & 5.5 to $9.0[21]$ \\
COD & $448 \mathrm{mg} / \mathrm{L}$ & $250 \mathrm{mg} / \mathrm{L}[21]$ \\
BOD & $173 \mathrm{mg} / \mathrm{L}$ & $30 \mathrm{mg} / \mathrm{L}[21]$ \\
Turbidity & $163.4 \mathrm{NTU}$ & $20 \mathrm{NTU}$ \\
\hline
\end{tabular}

\section{CONCLUSION}

In this study lead compounds were precipitated based on the $\mathrm{pH}$ dependant reaction. $\mathrm{Pb}, \mathrm{S}$ and $\mathrm{O}$ elemental composition and morphology was analyzed in that precipitation using SEM-EDX system. And also $\mathrm{Pb}$ concentration was determined by ICP-AES with the physicochemical parameters. This high concentration of $\mathrm{Pb}$ confirms that it is far greater than the permissible range and this effluent can increase the $\mathrm{Pb}$ concentration in the environment, which becomes hazardous to the living organisms. Physicochemical characteristics such as $\mathrm{pH}, \mathrm{COD}, \mathrm{BOD}$ and turbidity of the effluent tell the dangerous situation of the environment that leads to the severe damage to the aqua organisms and finally damages the tissues of human by accumulation, if this effluent gets released into the environment. To keep the pollution under control, the effluent must be treated well to reduce $\mathrm{Pb}$ concentration and other physicochemical properties before releasing into the environment.

\section{ACKNOWLEDGEMENTS}

The authors are grateful to The Head, Sophisticated Analytical Instrument Facility, Indian Institute of Technology, Bombay, India for providing ICP-AES. The authors also thankful to Mr. Karikrishna Yadav Nanganuru for his help in this work.

\section{Financial support and sponsorship: Nil.}

Conflict of Interests: There are no conflicts of interest.

\section{REFERENCES}

1. Liao, Dexiang, Wei Zheng, Xiaoming Li, Qi Yang, Xiu Yue, Liang Guo, and Guangming Zeng. Removal of lead (II) from aqueous solutions using carbonate hydroxyapatite extracted from eggshell waste. Journal of Hazardous Materials. 2010; 172(1): 126-130.

2. Mahmoud, Mohamed E., Maher M. Osman, Osama F. Hafez, Abdelrahman H. Hegazi, and Essam Elmelegy. Removal and preconcentration of lead (II) and other heavy metals from water by alumina adsorbents developed by surface-adsorbeddithizone. Desalination. 2010; 251(1): 123-130.

3. Naiya, Tarun Kumar, Ashim Kumar Bhattacharya, and Sudip Kumar Das. Adsorption of $\mathrm{Cd}$ (II) and $\mathrm{Pb}$ (II) from aqueous solutions on activated alumina.Journal of Colloid and Interface Science. 2009; 333(1):14-26.

4. Wang, Li, Jian Zhang, Ran Zhao, Ye Li, Cong Li, and Chenglu Zhang. Adsorption of $\mathrm{Pb}$ (II) on activated carbon prepared from Polygonum orientale Linn.: kinetics, isotherms, $\mathrm{pH}$, and ionic strength studies. Bioresource technology. 2010; 101(1); 5808-5814.

5. Sar1, Ahmet, and Mustafa Tuzen. Biosorption of cadmium (II) from aqueous solution by red algae (Ceramium virgatum): equilibrium, kinetic and thermodynamic studies. Journal of hazardous materials. 2008; 157(2): 448-454.

6. Apiratikul, Ronbanchob, Taha F. Marhaba, Suraphong Wattanachira, and Prasert Pavasant. Biosorption of binary mixtures of heavy metals by green macro alga, Caulerpa lentillifera. Songklanakarin J Sci Technol. 2004; 26(2): 199-207.

7. El-Sayed, M. Soltan, M. Mohamed Rehab, and A. Shoreit Ahmed. Behavioral response of resistant and sensitive Pseudomonas aeruginosa S22 isolated from Sohag Governorate, Egypt to cadmium stress. African Journal of Biotechnology. 2008; 7(14): 1-7.

8. Jung, C. H., T. Matsuto, N. Tanaka, and T. Okada. Metal distribution in incineration residues of municipal solid waste (MSW) in Japan. Waste Management. 2004; 24(4): 381-391.

9. Poikolainen, J., E. Kubin, J. Piispanen, and J. Karhu. Atmospheric heavy metal deposition in Finland during 1985-2000 using mosses as bioindicators.Science of the Total Environment. 2004; 318(1): 171185.

10. Malik, Anushree. Metal bioremediation through growing cells. Environment international. 2004; 30(2): 261-278.

11. Coral, Mutlu Nisa UNALDI, Hatice Korkmaz, Burhan Arikan, and Gökhan Coral. Plasmid mediated heavy metal resistances in 
Enterobacter spp. isolated from Sofulu landfill, in Adana, Turkey. Annals of microbiology. 2005; 55(3): 175.

12. Murthy, Shruti, Geetha Bali, and S. K. Sarangi. Effect of lead on growth, protein and biosorption capacity of Bacillus cereus isolated from industrial effluent. Journal of Environmental Biology. 2014; 35(2): 407-411.

13. Rathnayake, Ileperumaarachchige, Mallavarapu Megharaj, Nanthi Bolan, and Ravi Naidu. Tolerance of heavy metals by gram positive soil bacteria. PhD diss., World Academy of Science Engineering and Technology, 2009.

14. Cervantes, Carlos, Jesús Campos-García, Silvia Devars, Félix Gutiérrez-Corona, Herminia Loza-Tavera, Juan Carlos TorresGuzmán, and Rafael Moreno-Sánchez. Interactions of chromium with microorganisms and plants.FEMS Microbiology Reviews. 2001; 25(2): 335-347.

15. Fritsche, W. Environmental microbiology. Principles and applications. Umwelt-Mikrobiologie. Grundlagen und Anwendungen. 1998.

16. Ledin, Maria. Accumulation of metals by microorganismsprocesses and importance for soil systems. Earth-Science Reviews. 2000; 51(1): 1-31.

17. Lanphear, Bruce P., Richard Hornung, Jane Khoury, Kimberly Yolton, Peter Baghurst, David C. Bellinger, Richard L. Canfield et al. Low-level environmental lead exposure and children's intellectual function: an international pooled analysis. Environmental health perspectives. 2005; 894-899.

18. http://www.epa.gov/history/topics/perspect/lead accessed on $22 / 01 / 2016$

19. Standard methods for the examination of water and wastewater. Washington, DC: American Public Health Association, 2012.

20. http://www.epa.gov/osw/hazard/testmethods/sw846/pdfs/3015a.pdf accessed on 22/01/2016

21. IS 10500 (1992) Drinking water specifications hppcb.nic.in/EIAsorang/Spec.pdf accessed on 30/01/2016

22. http://water.epa.gov/drink/contaminants/ accessed on 22/01/2016

23. http://www.who.int/water_sanitation_health/dwq/GDWAN4rev1and 2.pdf?ua $=1$ accessed on 30/01/2016

24. http://www.rsic.iitb.ac.in/Icp-Aes.html accessed on 12/01/2016

25. Espinoza, E., R. Escudero, and F. J. Tavera. Waste Water Treatment by Precipitating Copper, Lead and Nickel Species. Research Journal of Recent Sciences, ISSN 2277. 2012; 2502.

26. Kazi, Tasneem Gul, Faheem Shah, Hassan Imran Afridi, Sumaira Khan, Sadaf Sadia Arian, and Kapil Dev Brahman. A green preconcentration method for determination of cobalt and lead in fresh surface and waste water samples prior to flame atomic absorption spectrometry. Journal of analytical methods in chemistry 2012 (2012) doi:10.1155/2012/713862.

27. http://water.epa.gov/scitech/methods/cwa/bioindicators/upload/2007_ 07_10_methods_method_200_7.pdf accessed 30/01/2016

28. http://www.4oakton.com/SellSheets/35419-00.pdf accessed on $12 / 01 / 2016$

29. Adachi, Kouji, and Peter R. Buseck. Hosted and free-floating metalbearing atmospheric nanoparticles in Mexico City. Environmental science \& technology. 2010; 44(7): 2299-2304.

30. Li, W. J., L. Y. Shao, and P. R. Buseck. Haze types in Beijing and the influence of agricultural biomass burning. Atmospheric Chemistry and Physics. 2010; 10(17): 8119-8130.

31. Lu, Sen-lin, Long-yi Shao, Ming-hong Wu, and Zheng Jiao Mineralogical characterization of airborne individual particulates in Beijing PM 10. Journal of Environmental Sciences. 2006; 18(1): 9095.

32. Shi, Zongbo, Longyi Shao, Timothy Peter Jones, A. G. Whittaker, Senlin Lu, Kelly Ann Berube, Taoe He, and Roy John Richards. Characterization of airborne individual particles collected in an urban area, a satellite city and a clean air area in Beijing, 2001. Atmospheric environment. 2003; 37(29): 4097-4108.

33. Li, Weijun, Longyi Shao, Zhishi Wang, Rongrong Shen, Shusheng Yang, and Uwa Tang. Size, composition, and mixing state of individual aerosol particles in a South China coastal city. Journal of Environmental Sciences. 2010; 22(4): 561-569.

34. Bérubé, K. A., T. P. Jones, B. J. Williamson, C. Winters, A. J. Morgan, and R. J. Richards. Physicochemical characterisation of diesel exhaust particles: Factors for assessing biological activity. Atmospheric Environment. 1999; 33(10): 1599-1614.

\section{How to cite this article:}

Korrapati N, Saroj P, Gaur N. Morphological and Elemental analysis of the effluent of Lead acid battery manufacturing. J App Biol Biotech. 2017; 5 (03): 052-056. DOI: 10.7324/JABB.2017.50309 